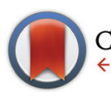

CrossMark \&click for updates

Cite this: Org. Biomol. Chem., 2017 15, 470

Received 28th October 2016, Accepted 24th November 2016

DOI: $10.1039 / c 6 o b 02346 k$

www.rsc.org/obc

\section{The first total synthesis of the marine acetylenic alcohol, lembehyne B - a selective inducer of early apoptosis in leukemia cancer cells $\uparrow$}

\author{
Lilya U. Dzhemileva, ${ }^{a}, \mathrm{~b}$ Vladimir A. D'yakonov, ${ }^{\text {a }}$ Aleksey A. Makarov, ${ }^{a}$ \\ Evgeny N. Andreev, ${ }^{a}$ Milyausha M. Yunusbaeva ${ }^{a}$ and Usein M. Dzhemilev ${ }^{a}$
}

\begin{abstract}
The communication reports a new stereoselective method for the synthesis of a natural acetylenic alcohol, lembehyne B. The key stage of the process uses new cross-cyclomagnesiation reaction of aliphatic and oxygenated 1,2-dienes with Grignard reagents in the presence of a catalytic amount of $\mathrm{Cp}_{2} \mathrm{TiCl}_{2}$. A study of the cytotoxic properties of lembehyne B on tumor cell lines using flow cytometry demonstrated that this is a selective inducer of early apoptosis of the Jurkat, HL-60 and K562 cell cultures and hypodiploid (sub-G1) sub-population inducer in cell cycle studies for all cell lines used.
\end{abstract}

\section{Introduction}

The Global Ocean occupies more than $70 \%$ of the Earth's surface; therefore, flora and fauna inhabiting the Ocean are considered as important sources of biologically active compounds that could serve as the base for the development of modern pharmaceutical agents for treating cancer, neurodegenerative diseases, viral and bacterial infections, and other dangerous human diseases. ${ }^{1}$ During the last decade alone, about ten thousand new compounds were isolated from marine organisms; some of these compounds are already under Phase I or II clinical trials. ${ }^{2}$

Recently, ${ }^{3}$ Kobayashi and co-workers isolated, from the Indonesian marine sponge Haliclona sp., micro quantities (10-15 $\mathrm{mg} \mathrm{kg}{ }^{-1}$ ) of lembehynes A-C - acetylenic alcohols (Fig. 1), efficient small-molecule analogues of proteins belonging to the family of neurotrophins, which perform an important function of maintaining the vitality of neurons. ${ }^{4}$ Hence, lembehynes are considered as potential pharmaceutical drugs for treating neurodegenerative diseases such as Alzheimer's disease, Parkinson's disease, and Huntington's chorea.

The poor accessibility and the lack of efficient methods for the synthesis of natural lembehynes hamper detailed investi-

\footnotetext{
${ }^{a}$ Institute of Petrochemistry and Catalysis, Russian Academy of Sciences, 141 Prospekt Oktyabrya, 450075 Ufa, Russian Federation.

E-mail: DyakonovVA@gmail.com; Fax:+73472842750; Tel: +73472842750

${ }^{b}$ Department of Immunology and Human Reproductive Health Bashkir State Medical University, Lenin Street, 3, 450003 Ufa, Russian Federation.

E-mail:Dzhemilev@mail.ru

$\dagger$ Electronic supplementary information (ESI) available. See DOI: 10.1039/ c6ob02346k
}

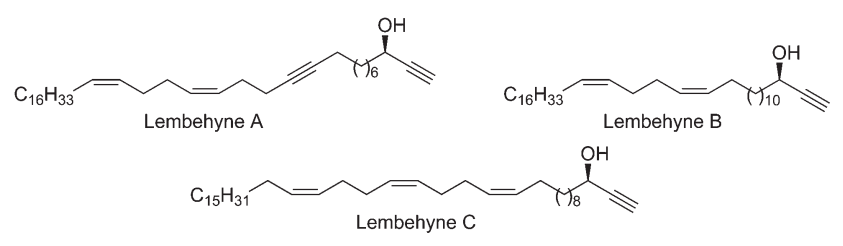

Fig. 1 Structures of lembehynes A-C.

gation of the properties and preclude taking full advantage of the biomedical potential of these compounds. ${ }^{5}$

Analysis of the lembehyne structure demonstrated that stereoselective formation of the $1 Z, 5 Z$-diene moiety present in the lembehyne molecule is the most complicated and multistep part. ${ }^{5}$ Indeed, in the 11-step total synthesis of lembehyne A, six steps were spent for the preparation of the key synthon, 4Z,8Z-pentacosa-4,8-dien-1-ol. ${ }^{5}$

Proceeding from the published data, the most popular approaches to the formation of the $1 Z, 5 Z$-diene moiety are based on the Wittig reaction, alkene metathesis, alkylation of alkynes, and stereoselective reduction of 1,5-diynes. ${ }^{6}$

Previously, we developed Ti-catalyzed homo- and crosscyclomagnesiation reactions of 1,2-dienes with Grignard reagents (Scheme 1), which were successfully used in the strictly stereoselective syntheses of $1 Z, 5 Z$-dienes of a specified structure, giant macrocarbocycles, and natural 5Z,9Z-dienoic acids exhibiting antitumor activities. ${ }^{7}$

In view of the foregoing, in this paper we report the development of a preparative stereoselective synthesis of lembehyne $\mathrm{B}$ using cross-cyclomagnesiation of aliphatic and oxygenated 1,2-dienes in the key stage of the synthesis, 


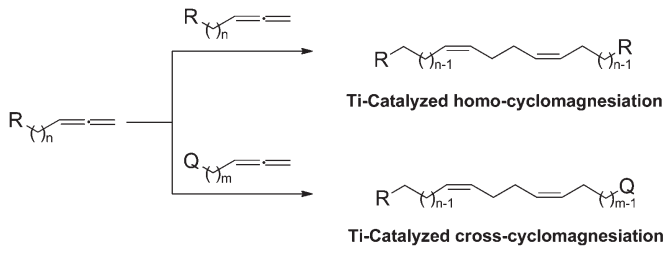

$\mathrm{R}=$ alkyl, aryl, cyclo, hetero;

$\mathrm{Q}=\mathrm{SiR}_{3}, \mathrm{NR}_{2}, \mathrm{OTHP}, \mathrm{OEE}, \mathrm{OBn}$

Scheme 1 Ti-Catalyzed homo- and cross-cyclomagnesiation.

product accumulation and in vitro testing for the antitumor activity on Jurkat, HL-60, and K562 cell lines using flow cytometry.

\section{Results and discussion}

By retrosynthetic analysis of the lembehyne $B$ structure, we identified the key monomer: (13Z,17Z)-tetraconta-13,17-dienal, which is accessible through cross-magnesiation of 1,2-nonadecadiene (1) with the tetrahydropyran ether of 13,14-pentadecadienol (2a) or 2-tetradeca-12,13-dien-1-yl-1,3-dioxolane (2b) (Scheme 2). The final steps are intended for the formation of the terminal propargyl moiety to obtain racemic lembehyne $\mathrm{B}$ and hydroxy group oxidation followed by stereoselective reduction (Scheme 2).

In accordance with the developed strategy, 1,2-nonadecadiene (1) and 13,14-pentadecadienol tetrahydropyran ether (2a) were first subjected to cross-cyclomagnesiation on treatment with EtMgBr in the presence of $\mathrm{Mg}$ metal and $\mathrm{Cp}_{2} \mathrm{TiCl}_{2}$ catalyst (10 $\mathrm{mol} \%$ ). The reaction proceeded via magnesacyclopentane 3a, which was hydrolyzed to give $(13 Z, 17 Z)$-tetraconta-13,17-dienol tetrahydropyran ether (4) in $88 \%$ yield (Scheme 3 ). Successive tetrahydropyran deprotection ${ }^{8}$ and Dess-Martin periodinane oxidation of unsaturated alcohol $5^{9}$ yielded the target $(13 Z, 17 Z)$ tetraconta-13,17-dienal (6) in $\sim 64 \%$ yield over two steps.

In turn, cross-magnesiation of 1,2-nonadecadiene (1) and 2-tetradeca-12,13-dien-1-yl-1,3-dioxolane (2b) with EtMgBr in the presence of $\mathrm{Mg}$ metal (halide ion acceptor) and a catalytic amount of $\mathrm{Cp}_{2} \mathrm{TiCl}_{2}(10 \mathrm{~mol} \%)(\mathbf{1}: 2 \mathbf{b}: \mathrm{EtMgBr}: \mathrm{Mg}:[\mathrm{Ti}]=$ $12: 10: 30: 20: 0.1, \mathrm{Et}_{2} \mathrm{O}, 20-22{ }^{\circ} \mathrm{C}, 7 \mathrm{~h}$ ) furnishes magnesacyclopentane $\mathbf{3 b}$, which is acid-hydrolyzed to afford $(13 Z, 17 Z)$ tetraconta-13,17-dienal (6) in $\sim 77 \%$ yield in one preparative step (Scheme 3).

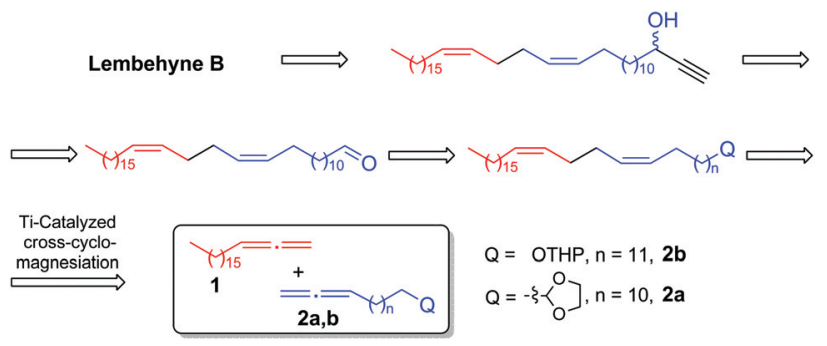

Scheme 2 Retrosynthetic analysis of lembehyne B.

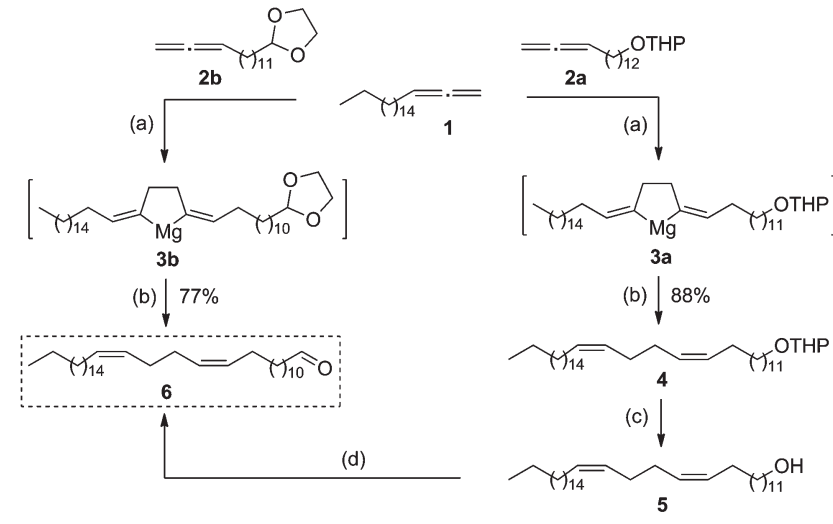

Scheme 3 Ti-Catalyzed cross-cyclomagnesiation of aliphatic and oxygenated 1,2-dienes in the synthesis of $(13 Z, 17 Z)$-tetraconta-13,17-dienal (6). Reagents and condition: (a) $\mathrm{EtMgBr}, \mathrm{Mg}, \mathrm{Cp}_{2} \mathrm{TiCl}_{2}, \mathrm{Et}_{2} \mathrm{O}$, rt; (b) $\mathrm{H}^{+}$; (c) $p-\mathrm{TsOH}, \mathrm{MeOH} / \mathrm{CHCl}_{3}, 77 \%$; (d) Dess-Martin periodinane, THP, rt, $83 \%$.

Thus, the yield of $(13 Z, 17 Z)$-tetraconta-13,17-dienal was $64 \%$ according to the former route and $77 \%$ according to the latter one.

At the final step, aldehyde $\mathbf{6}$ was made to react with lithium trimethylsilylacetylenide, ${ }^{10}$ prepared beforehand by the reaction of equimolar amounts of trimethylsilylacetylene and $n$-BuLi in THF, the reaction affording silane 7 in $90 \%$ yield over a period of 3 days at room temperature. The trimethylsilyl deprotection on treatment with tetrabutylammonium fluoride (TBAF) in THF over a period of $4 \mathrm{~h}$ furnished racemic lembehyne B (8) in nearly quantitative yield (Scheme 4).

Using racemic lembehyne $\mathrm{B}$, we synthesized its natural stereomer with the $3 R$-configuration of the hydroxy group at the C-3 carbon atom. First, Dess-Martin periodinane oxidation of alkynol 8 in $\mathrm{CH}_{2} \mathrm{Cl}_{2}$ at room temperature gave $(15 Z, 19 Z)$ hexaconta-15,19-dien-1-yl-3-one (9) in 86\% yield over a period of $1 \mathrm{~h}$ (Scheme 4). The stereoselective reduction of ketone 9 was performed using the B-3-pinanyl-9-borabicyclo[3.3.1] nonane (Alpine-borane) reagent, ${ }^{11}$ prepared beforehand from (+)- $\alpha$-pinene (98\% ee) and 9-borabicyclo[3.3.1]nonane. This gave lembehyne B (10) with enantiomeric excess of $95 \%$ in $84 \%$ yield.

During the last 10-15 years, several hundred natural alkynes, exhibiting high antitumor activities, were isolated from macro- and microalgae, freshwater- and marine cyanobacteria, and other marine organisms. ${ }^{2}$ Meanwhile, no data on the antitumor activity of natural lembehynes are available

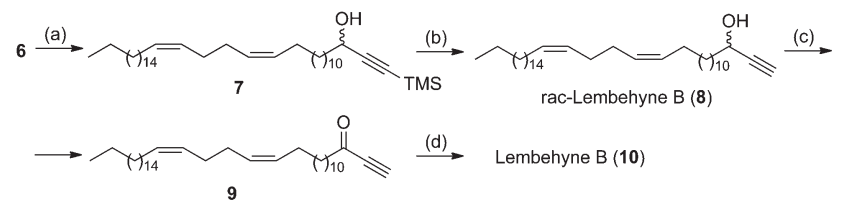

Scheme 4 Synthesis of lembehyne B. Reagents and condition: (a) lithium trimethylsilylacetylenide, THF, rt, 90\%; (b) TBAF, THF, rt, 99\%; (c) Dess-Martin periodinane, THF, rt, 86\%; (d) Alpine-borane, THF, rt, $84 \%$. 

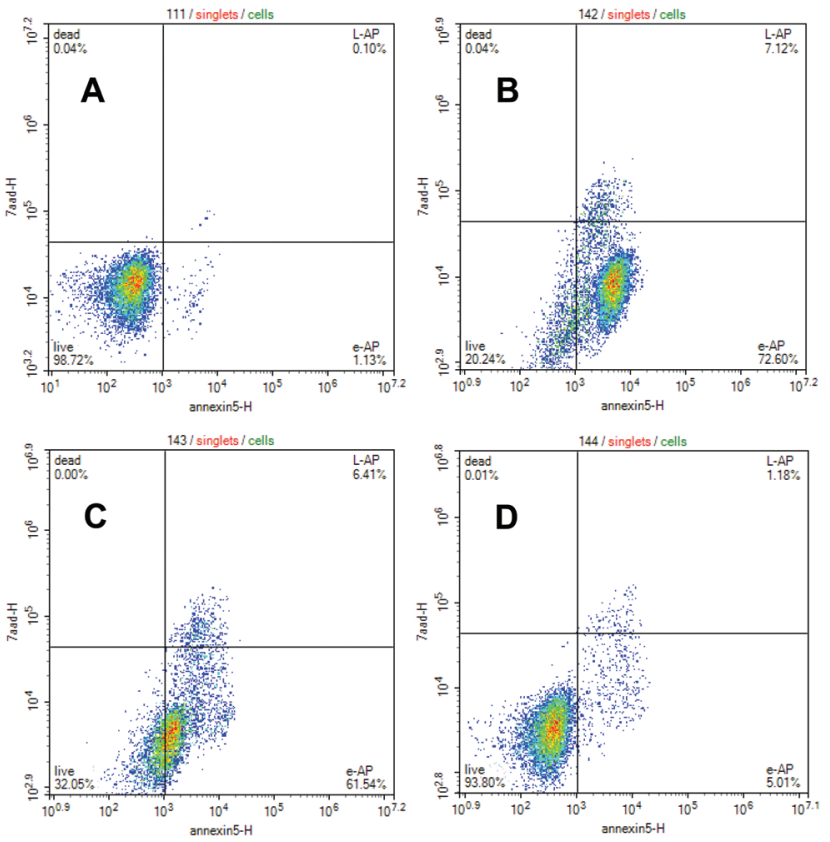

Fig. 2 Jurkat cells treated with different concentrations of lembehyne $B$ (10) were double-stained with annexine V/PI and analyzed by flow cytometry. (A) Control; (B) 10, $2 \mu \mathrm{M}$; (C) 10, $1 \mu \mathrm{M}$; (D) 10, $0.5 \mu \mathrm{M}$.

from the literature. Therefore, we performed the first in vitro tests of lembehyne B for the antitumor activity on leukemia cells (Jurkat, HL-60 and K562). The tests included determination of $\mathrm{IC}_{50}$, study of cell viability and effect on the cell cycle by means of flow cytofluorometry.
The quantitative and qualitative analyses of cell viability, cell cycle, and apoptosis-inducing activity of lembehyne B were performed using the Guava Nexin Reagent and Guava Cell Cycle (Millipore).

The in vitro cytotoxic activity of lembehyne B against Jurkat, HL-60, and K562 human leukemia cells was studied using Guava ViaCount (Millipore). Lembehyne B in concentrations of 0.5 to $4 \mu \mathrm{M}$ exhibited a clear-cut cytotoxic effect against all types of cancer cells we studied. However, the highest $\mathrm{IC}_{50}$ value was found for $\mathrm{K} 562$ cells $(3 \mu \mathrm{M})$, whereas for Jurkat and HL-60, the $\mathrm{IC}_{50}$ values were $2 \mu \mathrm{M}$ and $2.2 \mu \mathrm{M}$, respectively.

The lembehyne B-induced apoptosis in Jurkat, HL-60, and K562 cell cultures was estimated by detection of phosphatidylserine externalization on the plasmatic membrane after treatment of cell cultures with the test compound. It is noteworthy that the effect of lembehyne on the induction of apoptosis is more pronounced in Jurkat cells than in other cells, which is consistent with high cytotoxicity of the compound against this cell line. As can be seen from Fig. 2, exposure of Jurkat tumor cell culture to lembehyne $\mathrm{B}$ results in a considerable dosedependent increase in the amount of apoptotic cells occurring at early stage of apoptosis. The highest percentage of early apoptosis $(72.6 \%)$ is observed at $2 \mu \mathrm{M}$ concentration of the test compounds. In particular, as shown in Fig. 2, for Jurkat cells, both early and late stages of apoptosis are enhanced as compared with HL60 $(P \leq 0.0001)$ or K562 $(P \leq 0.0001)$.

According to cell cycle data determined by Guava Cell Cycle Reagent (Fig. 3), lembehyne B is a potent inducer of hypodiploid cell population (sub-G1 phase) in all three cell lines after the appropriate treatment with the test compounds. No
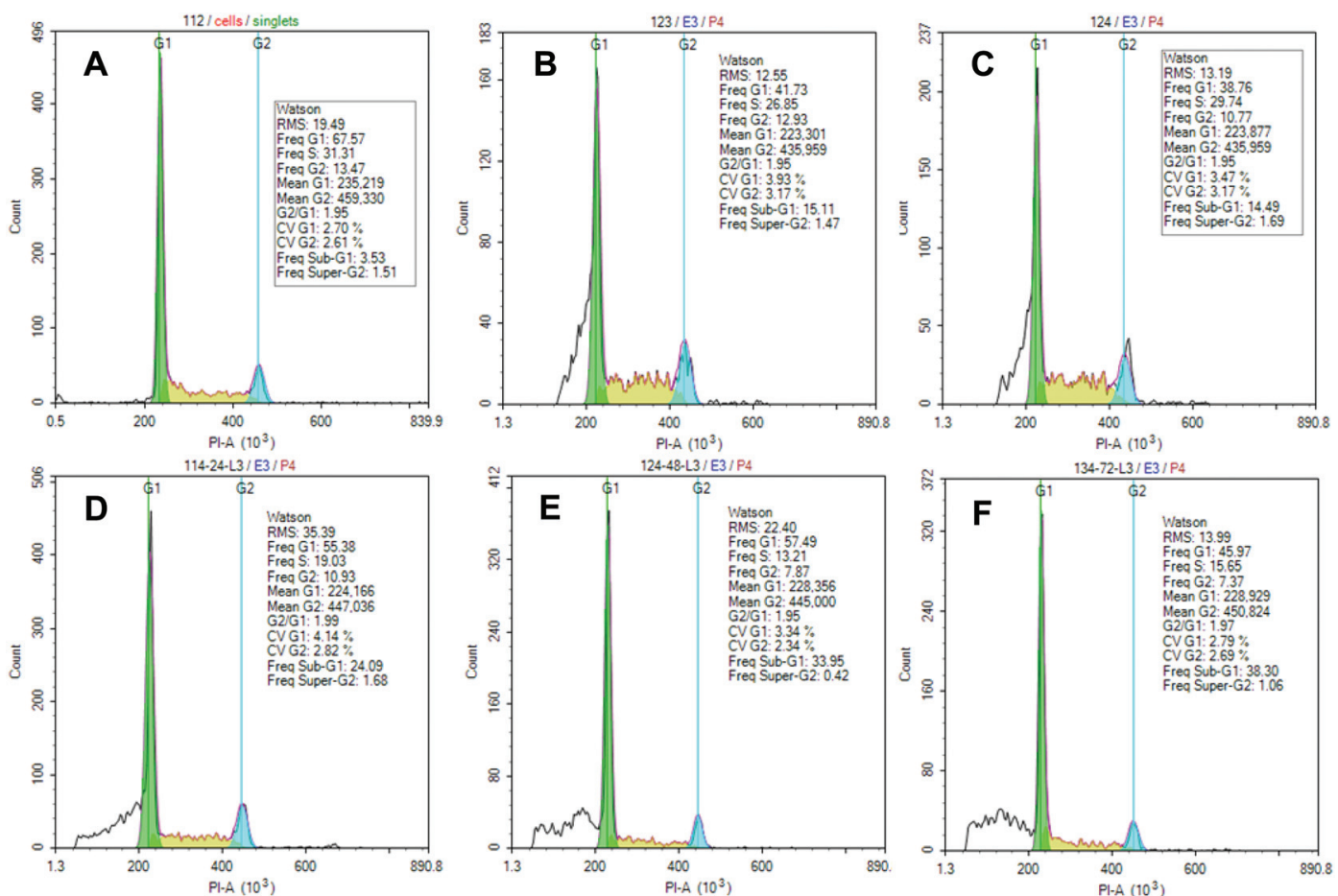

Fig. 3 Cell cycle phases for Jurkat cell line. Upper row: (A) control, (B) 10, $2 \mu \mathrm{L}$, (C) 10, $1 \mu \mathrm{L}$. Lower row: (10, $2 \mu \mathrm{L})$ : (D) $24 \mathrm{~h}$, (E) $48 \mathrm{~h},(\mathrm{~F}) 72 \mathrm{~h}$. 
significant differences were identified between cell-cycle distribution of cell subpopulations for lembehyne B-treated Jurkat, HL-60, and K562 cells.

\section{Conclusions}

Thus, an original stereoselective method for the synthesis of lembehyne B was developed for the first time. The key stage of the synthesis was based on the new reaction that we developed, namely, Ti-catalyzed cross-cyclomagnesiation of oxygenated aliphatic 1,2-dienes with Grignard reagents. We believe that this method bears huge synthetic potential for the preparation of stereochemically pure lembehynes and their analogues by varying the structure of the starting 1,2-dienes. By means of flow cytometry, it was shown for the first time that lembehyne $\mathrm{B}$ is a selective early apoptosis inducer for the Jurkat, HL-60, and K562 cell cultures. Currently, active research along this line is in progress in order to implement stereoselective methods for the synthesis of the whole range of natural lembehynes and their analogues for performing, in particular, full-scale pharmacological investigations of the biological activity and structure-activity relationships.

\section{Experimental section}

\section{General methods}

${ }^{1} \mathrm{H}$ and ${ }^{13} \mathrm{C}$ NMR spectra were obtained using a Bruker Ascend 500 spectrometer in $\mathrm{CDCl}_{3}$ operating at $500 \mathrm{MHz}$ for ${ }^{1} \mathrm{H}$ and $125 \mathrm{MHz}$ for ${ }^{13} \mathrm{C}$ and Bruker AVANCE 400 spectrometer in $\mathrm{CDCl}_{3}$ operating at $400 \mathrm{MHz}$ for ${ }^{1} \mathrm{H}$ and $100 \mathrm{MHz}$ for ${ }^{13} \mathrm{C}$. Mass spectra were obtained with a MALDI TOF/TOF spectrometer in a $\alpha$-cyano-4-hydroxycinnamic acid matrix. Elemental analyses were measured on a 1106 Carlo Erba apparatus. Individuality and purity of the synthesized compounds were controlled using TLC on Sorbfil plates; anisic aldehyde in acetic acid was used as a developer. Column chromatography was carried out on Acrus silica gel (0.060-0.200 mm). Flow cytometry studies were obtained using a NovoCyte ${ }^{\mathrm{TM}} 2000$ FlowCytometry System (ACEA). All solvents were dried (1,4-dioxane, tetrahydrofuran, diethyl ether over $\mathrm{Na}$ ) and freshly distilled before use. All reactions were carried out under a dry argon atmosphere. Aliphatic and oxygenated 1,2-dienes have been synthesized according procedures. ${ }^{7 g, 10,12,13}$

\section{Methods of synthesis and characterization data of all compounds}

Synthesis of 2-(pentadeca-13,14-dien-1-yloxy)tetrahydro- $2 \mathrm{H}$ pyran (2a). Paraformaldehyde (2.6 g), copper iodide (3.4 g, $17.8 \mathrm{mmol})$, and dicyclohexylamine $(14.0 \mathrm{~mL}, 70.4 \mathrm{mmol})$ were sequentially added to a solution of 2-(tetradec-13-yn-1-yloxy) tetrahydro- $2 H$-pyran $(10.0 \mathrm{~g}, 34.0 \mathrm{mmol})$ in anhydrous dioxane $(120 \mathrm{~mL})$. The resulting mixture was heated under reflux for $24 \mathrm{~h}$. The addition of $2 \mathrm{M} \mathrm{HCl}(50 \mathrm{~mL})$ and extraction with diethyl ether was followed by an extraction of the organic layer with $\mathrm{NaHCO}_{3}$, water, and brine and a drying with anhydrous $\mathrm{MgSO}_{4}$. The solvent was evaporated in vacuo, and the residue was purified by silica gel column chromatography (hexane/ ethyl acetate $=30 / 1)$ to afford 2-(pentadeca-13,14-dien-1-yloxy) tetrahydro-2H-pyran (2a) $(8.1 \mathrm{~g}, 78 \%)$ as colorless liquid.

2-(Pentadeca-13,14-dien-1-yloxy)tetrahydro-2 $\mathrm{H}$-pyran (2a). Found (\%): C, 77.69; H, 11.73. Calc. for $\mathrm{C}_{20} \mathrm{H}_{36} \mathrm{O}_{2}$ (\%): C, 77.87; H, 11.76. IR (film) $\nu_{\max } 2928,2851,1463,1379,1354$, 1301, 1248, 1108, 1068, 815, $722 \mathrm{~cm}^{-1} .{ }^{1} \mathrm{H}$ NMR $(400 \mathrm{MHz}$, $\left.\mathrm{CDCl}_{3}\right) \delta: 1.24-1.42(18 \mathrm{H}, \mathrm{m}), 1.49-1.62(6 \mathrm{H}, \mathrm{m}), 1.71(1 \mathrm{H}, \mathrm{m})$, $1.83(1 \mathrm{H}, \mathrm{m}), 1.99(2 \mathrm{H}, \mathrm{m}), 3.38(1 \mathrm{H}, \mathrm{m}), 3.49(1 \mathrm{H}, \mathrm{m}), 3.73$ (1H, m), 3.87 (1H, m), $4.58(1 \mathrm{H}, \mathrm{m}), 4.64(2 \mathrm{H}, \mathrm{m}), 5.08(1 \mathrm{H}, \mathrm{m})$. ${ }^{13} \mathrm{C}$ NMR (100.62 MHz, $\mathrm{CDCl}_{3}$ ) $\delta: 208.5(\mathrm{C}), 98.8(\mathrm{CH}), 90.0$ $(\mathrm{CH}), 74.4\left(\mathrm{CH}_{2}\right), 67.6\left(\mathrm{CH}_{2}\right), 62.2\left(\mathrm{CH}_{2}\right), 30.8\left(\mathrm{CH}_{2}\right), 29.8$ $\left(\mathrm{CH}_{2}\right), 29.6$ (signals of $\left.4 \mathrm{C}, \mathrm{CH}_{2}\right), 29.5\left(\mathrm{CH}_{2}\right), 29.4\left(\mathrm{CH}_{2}\right), 29.1$ $\left(\mathrm{CH}_{2}\right), 29.1\left(\mathrm{CH}_{2}\right), 28.3\left(\mathrm{CH}_{2}\right), 26.2\left(\mathrm{CH}_{2}\right), 25.5\left(\mathrm{CH}_{2}\right), 19.7$ $\left(\mathrm{CH}_{2}\right)$.

Cross-cyclomagnesiation of nonadeca-1,2-diene (1) and 2-(pentadeca-13,14-dien-1-yloxy)tetrahydro- $2 \mathrm{H}$-pyran (2a) with EtMgBr in the presence of $\mathrm{Mg}$ metal and $\mathrm{Cp}_{2} \mathrm{TiCl}_{2}$ catalyst

Diethyl ether (30 mL), nonadeca-1,2-diene (1) (1.27 g, $4.8 \mathrm{mmol}$ ), 2-(pentadeca-13,14-dien-1-yloxy)tetrahydro- $2 \mathrm{H}$ pyran (2a) (1.23 g, $4.0 \mathrm{mmol})$, EtMgBr (16.0 mmol) (as $1.5 \mathrm{M}$ solution in $\left.\mathrm{Et}_{2} \mathrm{O}\right), \mathrm{Mg}$ powder $(0.29 \mathrm{~g}, 12.0 \mathrm{mmol})$ and $\mathrm{Cp}_{2} \mathrm{TiCl}_{2}(0.1 \mathrm{~g}, 0.4 \mathrm{mmol})$ were placed in a glass reactor with stirring under argon $\left(\sim 0{ }^{\circ} \mathrm{C}\right)$. The reaction mixture was warmed-up to room temperature $\left(20-22^{\circ} \mathrm{C}\right)$ and stirred for $6 \mathrm{~h}$. The reaction mixture was treated with a $5 \%$ solution of $\mathrm{NH}_{4} \mathrm{Cl}$ in $\mathrm{H}_{2} \mathrm{O}(20 \mathrm{~mL})$ and extracted with diethyl ether $(2 \times 100 \mathrm{~mL})$. The combined organic phases were dried over $\mathrm{MgSO}_{4}$, filtered, and the solvents were removed under reduced pressure. Silica gel column chromatography (hexane/EtOAc (35/1)) of the residue gave compound $5(1.98 \mathrm{~g}, 88 \%)$ as a pale yellow oily liquid.

2-[(13Z,17Z)-Tetraconta-13,17-dien-1-yloxy]tetrahydro-2H-pyran (4). MS (MALDI-TOF), $m / z: 574[\mathrm{M}]^{+}$. Found (\%): C, 81.29; H, 12.94. Calc. for $\mathrm{C}_{39} \mathrm{H}_{74} \mathrm{O}_{2}$ (\%): C, 81.46; H, 12.97. IR (film) $\nu_{\max } 2929,2853,1465,1384,1360,1303,1256,1110,1075,815$, $722 \mathrm{~cm}^{-1} .{ }^{1} \mathrm{H}$ NMR $\left(400 \mathrm{MHz}, \mathrm{CDCl}_{3}\right) \delta: 0.90(3 \mathrm{H}, \mathrm{t}, J=6 \mathrm{~Hz})$, 1.25-1.41 (46H, m), 1.52-1.63 (6H, m), 1.72-1.73 (1H, m), 1.84-1.86 (1H, m), 2.03-2.09 (8H, m), 3.36-3.42 (1H, m), 3.48-3.54 (1H, m), 3.72-3.77 (1H, m), 3.86-3.91 (1H, m), 4.58-4.61 (1H, m), 5.34-5.43 (4H, m). ${ }^{13} \mathrm{C} \mathrm{NMR} \mathrm{(100.62} \mathrm{MHz,}$ $\left.\mathrm{CDCl}_{3}\right) \delta: 130.3(2 \mathrm{C}, \mathrm{CH}), 129.1(2 \mathrm{C}, \mathrm{CH}), 98.8(\mathrm{CH}), 67.7\left(\mathrm{CH}_{2}\right)$, $62.2\left(\mathrm{CH}_{2}\right), 31.9\left(\mathrm{CH}_{2}\right), 30.8\left(\mathrm{CH}_{2}\right), 29.8-29.3$ (signals of $21 \mathrm{C}$, $\left.\mathrm{CH}_{2}\right), 27.4\left(2 \mathrm{C}, \mathrm{CH}_{2}\right), 27.3\left(2 \mathrm{C}, \mathrm{CH}_{2}\right), 26.3\left(\mathrm{CH}_{2}\right), 25.5\left(\mathrm{CH}_{2}\right)$, $22.7\left(\mathrm{CH}_{2}\right), 19.7\left(\mathrm{CH}_{2}\right), 14.1\left(\mathrm{CH}_{3}\right)$.

THP-deprotection of ether (4) was carried out with $p$-TsOH in $\mathrm{CH}_{2} \mathrm{Cl}_{2} / \mathrm{MeOH}$ using known method ${ }^{8}$

(13Z,17Z)-Tetraconta-13,17-dien-1-ol (5). Yield 77\%. MS (MALDI-TOF), $m / z: 490[\mathrm{M}]^{+}$. Found (\%): C, 83.02; H, 13.57. Calc. for $\mathrm{C}_{34} \mathrm{H}_{66} \mathrm{O}(\%)$ : C, 83.19; H, 13.55. ${ }^{1} \mathrm{H}$ NMR $(400 \mathrm{MHz}$, $\left.\mathrm{CDCl}_{3}\right) \delta: 0.90(3 \mathrm{H}, \mathrm{t}, J=6 \mathrm{~Hz}), 1.25-1.42(46 \mathrm{H}, \mathrm{m}), 1.52-1.63$ (3H, m), 2.03-2.09 (8H, m), 3.64-3.67 (2H, m), 5.35-5.45 
(4H, m). ${ }^{13} \mathrm{C}$ NMR (100.62 MHz, $\left.\mathrm{CDCl}_{3}\right) \delta: 130.4(2 \mathrm{C}, \mathrm{CH})$, 129.2 (2C, $\mathrm{CH}), 63.1\left(\mathrm{CH}_{2}\right), 32.8\left(\mathrm{CH}_{2}\right), 31.9\left(\mathrm{CH}_{2}\right), 29.8-29.3$ (signals of $\left.19 \mathrm{C}, \mathrm{CH}_{2}\right), 27.4\left(2 \mathrm{C}, \mathrm{CH}_{2}\right), 27.2\left(2 \mathrm{C}, \mathrm{CH}_{2}\right), 25.7$ $\left(\mathrm{CH}_{2}\right), 22.7\left(\mathrm{CH}_{2}\right), 19.7\left(\mathrm{CH}_{2}\right), 14.1\left(\mathrm{CH}_{3}\right)$.

The oxidation of the alcohol (5) with Dess-Martin periodinane was carried out according known procedure ${ }^{9}$

(13Z,17Z)-Tetraconta-13,17-dien-1-al (6). Yield 83\%. MS (MALDI-TOF), $m / z: 488[\mathrm{M}]^{+}$. Found (\%): C, 83.39; H, 13.16. Calc. for $\mathrm{C}_{34} \mathrm{H}_{64} \mathrm{O}(\%)$ : C, 83.53; H, 13.20. ${ }^{1} \mathrm{H}$ NMR $(400 \mathrm{MHz}$, $\left.\mathrm{CDCl}_{3}\right) \delta: 0.91\left(3 \mathrm{H}, \mathrm{t}, \mathrm{CH}_{3}, J=6 \mathrm{~Hz}\right), 1.23-1.48\left(46 \mathrm{H}, \mathrm{m}, \mathrm{CH}_{2}\right)$, 1.59-1.66 (3H, m), 2.04-2.10 (8H, m, $\left.=\mathrm{CH}-\mathrm{CH}_{2}\right), 2.42-2.45$ $\left(2 \mathrm{H}, \mathrm{m}, \mathrm{O}=\mathrm{CH}-\mathrm{CH}_{2}\right), 5.39-5.40(4 \mathrm{H}, \mathrm{m},=\mathrm{CH}), 9.78-9.79(1 \mathrm{H}$, $\mathrm{m}, \mathrm{O}=\mathrm{CH}) .{ }^{13} \mathrm{C}$ NMR (100.62 $\mathrm{MHz}, \mathrm{CDCl}_{3}$ ) $\delta: 202.9(\mathrm{CH}), 130.4$ $(\mathrm{CH}), 129.1(\mathrm{CH}), 43.9\left(\mathrm{CH}_{2}\right), 31.9\left(\mathrm{CH}_{2}\right), 29.2-29.7$ (signals of 22C, $\left.\mathrm{CH}_{2}\right), 27.4\left(2 \mathrm{C}, \mathrm{CH}_{2}\right), 27.3\left(2 \mathrm{C}, \mathrm{CH}_{2}\right), 22.7\left(\mathrm{CH}_{2}\right), 22.1$ $\left(\mathrm{CH}_{2}\right), 14.1\left(\mathrm{CH}_{3}\right)$.

Cross-cyclomagnesiation of nonadeca-1,2-diene (1) and 2-tetradeca-12,13-dien-1-yl-1,3-dioxolane (2b) with EtMgBr in the presence of $\mathrm{Mg}$ metal and $\mathrm{Cp}_{2} \mathrm{TiCl}_{2}$ catalyst

Diethyl ether (30 mL), nonadeca-1,2-diene (1) (1.27 g, $4.8 \mathrm{mmol}$ ), 2-tetradeca-12,13-dien-1-yl-1,3-dioxolane (2b) (1.06 g, $4.0 \mathrm{mmol})$, EtMgBr $(30.0 \mathrm{mmol}$ ) (as 1.5 M solution in $\left.\mathrm{Et}_{2} \mathrm{O}\right), \mathrm{Mg}$ powder $(0.48 \mathrm{~g}, 20.0 \mathrm{mmol})$ and $\mathrm{Cp}_{2} \mathrm{TiCl}_{2}(0.1 \mathrm{~g}$, $0.4 \mathrm{mmol}$ ) were placed in a glass reactor with stirring under argon $\left(\sim 0{ }^{\circ} \mathrm{C}\right)$. The reaction mixture was warmed-up to room temperature $\left(20-22{ }^{\circ} \mathrm{C}\right)$ and stirred for $6 \mathrm{~h}$. The reaction mixture was treated with a $10 \%$ solution of $\mathrm{HCl}$ in $\mathrm{H}_{2} \mathrm{O}$ $(20 \mathrm{~mL})$ and extracted with diethyl ether $(2 \times 100 \mathrm{~mL})$. The combined organic phases were dried over $\mathrm{MgSO}_{4}$, filtered, and the solvents were removed under reduced pressure. Silica gel column chromatography (hexane/EtOAc (35/1)) of the residue gave dienal $6(1.50 \mathrm{~g}, 77 \%)$ as a pale yellow oily liquid.

\section{Procedure for preparation of alkyne (7)}

To a solution of trimethylsilyl acetylene $0.58 \mathrm{~g}(6 \mathrm{mmol})$ in THF $(10 \mathrm{ml})$ was added dropwise a solution of $4 \mathrm{ml} n$-BuLi (1.5 $\mathrm{M}$ in hexane) at $-40{ }^{\circ} \mathrm{C}$. The solution was stirred for $1 \mathrm{~h}$ at -40 to $0{ }^{\circ} \mathrm{C}$. Then the solution was added dropwise to THF solution of $1.5 \mathrm{~g}(3.08 \mathrm{mmol})$ dienal $(7)$ at $-10{ }^{\circ} \mathrm{C}$. The reaction mixture was warmed-up to room temperature $\left(20-22{ }^{\circ} \mathrm{C}\right)$ and stirred for 3 days. The reaction mixture was treated with a $5 \%$ solution of $\mathrm{NH}_{4} \mathrm{Cl}$ in $\mathrm{H}_{2} \mathrm{O}(20 \mathrm{~mL})$ and extracted with diethyl ether $(2 \times 100 \mathrm{~mL})$. The combined organic phases were dried over $\mathrm{MgSO}_{4}$, filtered, and the solvents were removed under reduced pressure. Silica gel column chromatography of the residue gave compound $7(1.63 \mathrm{~g}, 90 \%)$ as a pale yellow oily liquid.

(15Z,19Z)-1-(Trimethylsilyl)hexatriaconta-15,19-dien-1-yn-3-ol (7). MS (MALDI-TOF), $m / z: 587[\mathrm{M}]^{+}$. Found (\%): C, 79.62; H, 12.66. Calc. for $\mathrm{C}_{39} \mathrm{H}_{74} \mathrm{OSi}$ (\%): C, 79.79; $\mathrm{H}, 12.70 .{ }^{1} \mathrm{H} \mathrm{NMR}$ $\left(400 \mathrm{MHz}_{\mathrm{CDCl}}\right) \delta: 0.19\left(9 \mathrm{H}, \mathrm{s}, \mathrm{CH}_{3}\right), 0.90\left(3 \mathrm{H}, \mathrm{t}, \mathrm{CH}_{3}, J=\right.$ $6 \mathrm{~Hz}), 1.25-1.72\left(49 \mathrm{H}, \mathrm{m}, \mathrm{CH}_{2}\right), 2.04-2.11\left(8 \mathrm{H}, \mathrm{m},=\mathrm{CH}-\mathrm{CH}_{2}\right)$, $4.37(1 \mathrm{H}, \mathrm{t}, \mathrm{HO}-\mathrm{CH}, J=5 \mathrm{~Hz}), 5.38-5.41(4 \mathrm{H}, \mathrm{m},=\overline{\mathrm{CH}})$. ${ }^{13} \mathrm{C}$ NMR (100.62 $\left.\overline{\mathrm{MHz}}, \mathrm{CDCl}_{3}\right) \delta: 130.4(\mathrm{CH}), 129.2(\mathrm{CH})$,
$106.9(\mathrm{C}), 89.3(\mathrm{CH}), 62.9(\mathrm{CH}), 37.7\left(\mathrm{CH}_{2}\right), 31.9\left(\mathrm{CH}_{2}\right)$, 29.2-29.8 (signals of 22C, $\left.\mathrm{CH}_{2}\right), 27.4\left(2 \mathrm{C}, \mathrm{CH}_{2}\right), 27.3\left(2 \mathrm{C}, \mathrm{CH}_{2}\right)$, $25.1\left(\mathrm{CH}_{2}\right), 22.7\left(\mathrm{CH}_{2}\right), 14.1\left(\mathrm{CH}_{3}\right),-0.11\left(3 \mathrm{C}, \mathrm{CH}_{3}\right)$.

\section{Procedure for preparation of rac-lembehyne B (8)}

To a solution of alkyne (7) $1.17 \mathrm{~g}$ ( $2 \mathrm{mmol})$ in THF (10 ml) was added TBAF ( $1 \mathrm{M}$ in THF, 1.2 equiv.) at $0{ }^{\circ} \mathrm{C}$, then the solution was stirred for $4 \mathrm{~h}$ at room temperature. The reaction mixture was treated with saturated aq. $\mathrm{NaCl}$ and extracted with diethyl ether $(2 \times 50 \mathrm{~mL})$. The combined organic phases were dried over $\mathrm{MgSO}_{4}$, filtered, and the solvents were removed under reduced pressure. Silica gel column chromatography of the residue gave compound $8(1.07 \mathrm{~g}, 99 \%)$ as a colorless waxy solid.

The oxidation of the alcohol (8) with Dess-Martin periodinane was carried out according ${ }^{9}$

(15Z,19Z)-Hexaconta-15,19-dien-1-yl-3-one (9). Yield 86\%. MS (MALDI-TOF), $m / z: 512[\mathrm{M}]^{+}$. Found (\%): C, 84.09; H, 12.55. Calc. for $\mathrm{C}_{36} \mathrm{H}_{64} \mathrm{O}$ (\%): C, 84.30; H, 12.58. ${ }^{1} \mathrm{H}$ NMR $(400 \mathrm{MHz}$, $\left.\mathrm{CDCl}_{3}\right) \delta: 0.90\left(3 \mathrm{H}, \mathrm{t}, \mathrm{CH}_{3}, J=6 \mathrm{~Hz}\right), 1.23-1.48\left(44 \mathrm{H}, \mathrm{m}, \mathrm{CH}_{2}\right)$, 1.64-1.72 (2H, m, $\left.\mathrm{C}_{2}\right), 2.04-2.10\left(8 \mathrm{H}, \mathrm{m},=\mathrm{CH}-\mathrm{CH}_{2}\right)$, 2.58-2.62 (2H, m, O= $\left.\overline{\mathrm{CH}}-\mathrm{CH}_{2}\right), 3.22(1 \mathrm{H}, \mathrm{s}, \mathrm{CH}), 5.39-5.42$ $(4 \mathrm{H}, \mathrm{m},=\mathrm{CH}) .{ }^{13} \mathrm{C} \mathrm{NMR}\left(100.62 \mathrm{MHz} \mathrm{CDCl}_{3}\right) \delta: 187.5(\mathrm{C})$, $130.4(\mathrm{CH}), 130.3(\mathrm{CH}), 129.1(2 \mathrm{C}, \mathrm{CH}), 81.5(\mathrm{C}), 78.2(\mathrm{CH})$, $45.5\left(\mathrm{CH}_{2}\right), 31.9\left(\mathrm{CH}_{2}\right), 29.3-29.7$ (signals of $\left.19 \mathrm{C}, \mathrm{CH}_{2}\right), 28.9$ $\left(\mathrm{CH}_{2}\right), 27.4\left(2 \mathrm{C}, \mathrm{CH}_{2}\right), 27.3\left(2 \mathrm{C}, \mathrm{CH}_{2}\right), 22.7\left(\mathrm{CH}_{2}\right), 23.8\left(\mathrm{CH}_{2}\right)$, $14.1\left(\mathrm{CH}_{3}\right)$.

The stereoselective reduction of ketone 9 with $B$-3-pinanyl-9borabicyclo[3.3.1]nonane (Alpine-borane reagent) was carried out according procedure ${ }^{11}$

The spectral data of compound $\mathbf{1 0}$ were identical to previously published for lembehyne B. ${ }^{3 c}$

Lembehyne B (10). Yield 49\% (95\% ee). $[\alpha]_{\mathrm{D}}^{25}+0.43(c \quad 0.3$, $\left.\mathrm{CHCl}_{3}\right) .{ }^{1} \mathrm{H}$ NMR $\left(400 \mathrm{MHz}, \mathrm{CDCl}_{3}\right) \delta: 0.90\left(3 \mathrm{H}, \mathrm{t}, \mathrm{CH}_{3}, J=\right.$ $7 \mathrm{~Hz}), 1.23-1.54\left(44 \mathrm{H}, \mathrm{m}, \mathrm{CH}_{2}\right), 1.71-1.75\left(2 \mathrm{H}, \mathrm{m}, \mathrm{CH}_{2}\right)$, 2.04-2.10 (8H, m, = $\left.\mathrm{CH}-\mathrm{CH}_{2}\right), 4.39(1 \mathrm{H}, \mathrm{td}, J=7.0,2.0 \mathrm{~Hz})$, 5.39-5.41 (4H, m, = $\underline{\mathrm{H}}) .{ }^{13} \mathrm{C} \mathrm{NMR}\left(100.62 \mathrm{MHz}, \mathrm{CDCl}_{3}\right)$ $\delta$ : 130.4 (2C, CH), $129.2(2 \mathrm{C}, \mathrm{CH}), 85.0(\mathrm{C}), 72.8(\mathrm{CH}), 62.4$ $(\mathrm{CH}), 37.7\left(\mathrm{CH}_{2}\right), 31.9\left(\mathrm{CH}_{2}\right), 29.3-29.7$ (signals of $\left.19 \mathrm{C}, \mathrm{CH}_{2}\right)$, $29.2\left(\mathrm{CH}_{2}\right), 27.4\left(2 \mathrm{C}, \mathrm{CH}_{2}\right), 27.3\left(2 \mathrm{C}, \mathrm{CH}_{2}\right), 25.0\left(\mathrm{CH}_{2}\right), 22.7$ $\left(\mathrm{CH}_{2}\right), 14.1\left(\mathrm{CH}_{3}\right)$.

\section{Biology}

\section{Cell culture}

Human leukemia cells Jurkat, HL-60, K562 were obtained from the HPA Culture Collections (UK). The cell lines was cultured in RPMI (Gibco BRL) supplemented with 10\% fetal bovine serum and $1 \%$ penicillin-streptomycin solution at $37^{\circ} \mathrm{C}$ in a humidified incubator under a $5 \% \mathrm{CO}_{2}$ atmosphere. Testing compounds was dissolved in DMSO and diluted with the tissue culture medium before use. 


\section{Viability and apoptosis}

In vitro cytotoxicity was assessed using a standard MTT (3-(4,5dimethylthiazol-2-yl)-2,5-diphenyl-2 $H$-tetrazolium bromide) colorimetric assay. ${ }^{14}$ The $\mathrm{IC}_{50}$ value was determined from plots of $\%$ viability against the dose of the compound added. The percentage of cell growth inhibition was calculated as 100 minus (mean cell culture optical density in the test/mean cell culture optical density in the control) multiplied by 100 . The value obtained for the first three wells without addition of the test compound (control triplet), which was measured in parallel for each test compound, was taken to be $100 \%$. The mean value and the error of mean were calculated separately for each concentration of the test compound. The results were used to plot the cell viability (\%) versus the test compound concentration, and the dose inhibiting the cell viability by $50 \%$ $\left(\mathrm{IC}_{50}\right)$ and the standard error (SE) of $\mathrm{IC}_{50}$ were calculated using the GraphPad Prism 7.0 software (GraphPad Inc., USA).

Apoptosis was determined by flow cytometric analysis of Annexin V and 7-aminoactinomycin D staining. Briefly, $200 \mu \mathrm{l}$ of Guava Nexin reagent (Millipore, Bedford, MA, USA) was added to $5 \times 10^{5}$ cells in $200 \mu \mathrm{l}$, and the cells were incubated with the reagent for $20 \mathrm{~min}$ at room temperature in the dark. At the end of incubation, the cells were analyzed on NovoCyte $^{\mathrm{TM}} 2000$ FlowCytometry System (ACEA).

\section{Cell cycle analysis}

Cell cycle was analyzed using the method of propidium iodide staining. Briefly, cells were plated in 24-well round bottom plates at a density $10 \times 10^{5}$ cells per well, centrifuged at $450 \mathrm{~g}$ for 5 minutes, and fixed with ice-cold $70 \%$ ethanol for 24 hour at $0{ }^{\circ} \mathrm{C}$. Cells were then washed with PBS and incubated with $250 \mu \mathrm{l}$ of Guava Cell Cycle Reagent (Millipore) for 30 minutes at room temperature in the dark. Samples were analyzed on NovoCyte ${ }^{\mathrm{TM}} 2000$ FlowCytometry System (ACEA).

\section{Acknowledgements}

This work was financially supported by the Russian Science Foundation (Grant No. 16-13-10172). The structural studies of the synthesized compounds were performed with the use of Collective Usage Centre "Agidel" at the Institute of Petrochemistry and Catalysis of RAS. The biological studies of muricadienin were done in the Center for Molecular Design and Drug Bioscreening at the Institute of Petrochemistry and Catalysis of RAS that was created with the financial support of the Russian Science Foundation.

\section{Notes and references}

1 (a) T. L. Simmons, E. Andrianasolo, K. McPhail, P. Flatt and W. H. Gerwick, Mol. Cancer Ther., 2005, 4, 333-342; (b) G. M. Nicholas and A. J. Phillips, Nat. Prod. Rep., 2006, 23, 79-99; (c) J. W. Blunt, B. R. Copp, M. H. G. Munro, P. T. Northcote and M. R. Prinsep, Nat. Prod. Rep., 2006, 23,
26-78; (d) C. Chakraborty, C.-H. Hsu, Z.-H. Wen and C.-S. Lin, Curr. Top. Med. Chem., 2009, 9, 1536-1545; (e) I. Bhatnagar and S.-K. Kim, Mar. Drugs, 2010, 8, 27022720; $(f)$ R. Montaser and H. Luesch, Future Med. Chem., 2011, 3, 1475-1489; $(g)$ G. Schwartsmann, A. B. da Rocha, R. G. S. Berlinck and J. Jimeno, Lancet Oncol., 2001, 2, 221225.

2 (a) A. Siddiq and V. Dembitsky, Anti-Cancer Agents Med. Chem., 2008, 8, 132-170; (b) Z.-F. Zhou, M. Menna, Y.-S. Cai and Y.-W. Guo, Chem. Rev., 2015, 115, 1543-1596; (c) N. Fusetani, H. Y. Li, K. Tamura and S. Matsunaga, Tetrahedron, 1993, 49, 1203-1210; (d) G. Nuzzo, M. L. Ciavatta, G. Villani, E. Manzo, A. Zanfardino, M. Varcamonti and M. Gavagnin, Tetrahedron, 2012, 68, 754-760; (e) A. D. Patil, W. C. Kokke, S. Cochran, T. A. Francis, T. Tomszek and J. W. Westley, J. Nat. Prod., 1992, 55, 1170-1177; (f) J. H. Shin, Y. W. Seo, K. W. Cho, J.-R. Rho and V. J. Paul, Tetrahedron, 1998, 54, 8711-8720; (g) K. Watanabe, Y. Tsuda, Y. Yamane, H. Takahashi, K. Iguchi, H. Naoki, T. Fujita and R. W. M. Van Soest, Tetrahedron Lett., 2000, 41, 9271-9276; (h) S. Tsukamoto, H. Kato, H. Hirota and N. Fusetani, J. Nat. Prod., 1997, 60, 126-130; (i) S. Ohta, H. Okada, H. Kobayashi, J. M. Oclarit and S. Ikegami, Tetrahedron Lett., 1993, 34, 5935-5938; (j) D. Listunov, V. Maraval, R. Chauvin and Y. Génisson, Nat. Prod. Rep., 2015, 32, 49-75.

3 (a) S. Aoki, K. Matsui, K. Tanaka, R. Satari and M. Kobayashi, Tetrahedron, 2000, 56, 9945-9948; (b) S. Aoki, K. Matsui, T. Takata, W. Hong and M. Kobayashi, Biochem. Biophys. Res. Commun., 2001, 289, 558-563; (c) S. Aoki, K. Matsui, H. Wei, N. Murakami and M. Kobayashi, Tetrahedron, 2002, 58, 5417-5422.

4 (a) Y.-A. Barde, Neuron, 1989, 2, 1525-1534; (b) S. Korsching, J. Neurosci., 1993, 13, 2739.

5 N. Murakami, T. Nakajima and M. Kobayashi, Tetrahedron Lett., 2001, 42, 1941-1943.

6 (a) P. L. Mena, O. Pilet and C. Djerassi, J. Org. Chem., 1984, 49, 3260-3264; (b) D. Raederstorff, A. Y. L. Shu, J. E. Thompson and C. Djerassi, J. Org. Chem., 1987, 52, 2337-2346; (c) T. Nemoto, G. Yoshino, M. Ojika and Y. Sakagami, Tetrahedron, 1997, 53, 16699-16710; (d) E. D. Reyes and N. M. Carballeira, Synthesis, 1997, 11951198; (e) N. M. Carballeira, A. Emiliano, N. HernándezAlonso and F. A. González, J. Nat. Prod., 1998, 61, 15431546; $(f)$ N. M. Carballeira, A. Emiliano and A. Guzmán, Chem. Phys. Lipids, 1999, 100, 33-40; (g) N. M. Carballeira, J. E. Betancourt, E. A. Orellano and F. A. González, J. Nat. Prod., 2002, 65, 1715-1718; (h) B. A. Kulkarni, A. Sharma, S. Gamre and S. Chattopadhyay, Synthesis, 2004, 595-599; (i) N. M. Carballeira, R. O'Neill and D. Silva, Chem. Phys. Lipids, 2008, 156, 41-44; (j) I. Liblikas, R. Mozūraitis, E. M. Santangelo, R. Noreika and A.-K. Borg-Karlson, Chem. Biodiversity, 2009, 6, 1388-1403; (k) J. Adrian and C. B. W. Stark, Org. Lett., 2014, 16, 5886-5889; (l) J. Adrian and C. B. W. Stark, Eur. J. Org. Chem., 2016, 4607-4610; (m) J. Adrian and C. B. W. Stark, J. Org. Chem., 2016, 81, 
8175-8186; (n) J. Schmidt, J. Adrian and C. B. W. Stark, Org. Biomol. Chem., 2015, 13, 8173-8176; (o) R. A. Kunkalkar, D. Laha and R. A. Fernandes, Org. Biomol. Chem., 2016, 14, 9072-9079.

7 (a) U. M. Dzhemilev, V. A. D'yakonov, L. O. Khafizova and A. G. Ibragimov, Tetrahedron, 2004, 60, 1287-1291; (b) V. A. D'yakonov, A. A. Makarov, A. G. Ibragimov, L. M. Khalilov and U. M. Dzhemilev, Tetrahedron, 2008, 64, 10188-10194; (c) V. A. D'yakonov, A. A. Makarov, E. Kh. Makarova and U. M. Dzhemilev, Tetrahedron, 2013, 69, 8516-8526; (d) V. A. D’yakonov, A. A. Makarov, L. U. Dzhemileva, E. Kh. Makarova, E. K. Khusnutdinova and U. M. Dzhemilev, Chem. Commun., 2013, 49, 84018403; (e) V. A. D'yakonov, L. U. Dzhemileva, A. A. Makarov, A. R. Mulyukova, D. S. Baev, E. K. Khusnutdinova, T. G. Tolstikova and U. M. Dzhemilev, Med. Chem. Res., 2016, 25, 30-39; (f) V. A. D’yakonov, L. U. Dzhemileva, A. A. Makarov, A. R. Mulyukova, D. S. Baev, E. K. Khusnutdinova, T. G. Tolstikova and U. M. Dzhemilev, Bioorg. Med. Chem. Lett., 2015, 25, 2405-
2408; (g) U. M. Dzhemilev, V. A. D’yakonov, R. A. Tuktarova, L. U. Dzhemileva, S. R. Ishmukhametova, M. M. Yunusbaeva and A. de Meijere, J. Nat. Prod., 2016, 79, 2039-2044.

8 O. Kuisle, E. Quiñoá and R. Riguera, J. Org. Chem., 1999, 64, 8063-8075.

9 S. D. Meyer and S. L. Schreiber, J. Org. Chem., 1994, 59, 7549-7552.

10 L. Brandsma, Synthesis of Acetylenes, Allenes and Cumulenes: Methods and Techniques, Elsevier SPC, Amsterdam-OxfordNew York, 2004, p. 470.

11 M. M. Midland, A. Tramontano, A. Kazubski, R. S. Graham, D. J. S. Tsai and D. B. Cardin, Tetrahedron, 1984, 40, 13711380.

12 C. E. Janßen and N. Krause, Eur. J. Org. Chem., 2005, 23222329.

13 S. Chanthamath, H. W. Chua, S. Kimura, K. Shibatomi and S. Iwasa, Org. Lett., 2014, 16, 3408-3411.

14 K. Du, J. Liang, Y. Wang, J. Kou, C. Qian, L. Jia and H. Chao, Dalton Trans., 2014, 43, 17303-17316. 